\title{
Effects of a Wet-Dry Seed Treatment on the Germination and Root Elongation of "Whit- mar" Beardless Wheatgrass under Various Water Potentials
}

\author{
WALTER W. KASTNER, JR., CARL J. GOEBEL, AND JAMES D. MAGUIRE
}

\begin{abstract}
Seeds of Whitmar beardless wheatgrass (A gropyron spicatum $\mathrm{f}$. inerme Beetle) were allowed to imbibe water at $20^{\circ} \mathrm{C}$ for 24 hours, followed by air-drying at room temperature for 24 hours. Seeds were then placed in slanted-plate containers held at $20^{\circ} \mathrm{C}$ to measure germination and root elongation under water potentials of $-0.3,-7.5$, and -15 bars. Seed treatment significantly accelerated germination and root elongation under a water potential of $\mathbf{- 0 . 3}$ bars, with some acceleration occurring at $\mathbf{- 7 . 5}$ bars. Treatment did not accelerate growth activity under a water potential of -15 bars.
\end{abstract}

The loss of available forage on many lower elevation rangelands due to agricultural development, water impoundment, municipal and industrial expansion, as well as highway development, has increased the grazing pressure on the less accessible areas. These areas are often steep and rocky, which limits revegetation, in many cases, to broadcast seeding. On many such semiarid rangelands in the West, inadequate moisture and competition from aggressive annuals hinder the establishment of perennial forage grass seedings. In addition, bird and rodent depredation of broadcast seed can be an important factor in the success or failure of these operations (Goebel and Maguire 1976; Nelson et al. 1970). Successful establishment of broadcast seeded Whitmar beardless wheatgrass (Agropyron spicatum $\mathrm{f}$. inerme Beetle) has been demonstrated in fall reseeding along the Snake River breaks in southeastern Washington where seeds were protected from bird depredation (Goebel and Maguire 1976). Therefore, if seed germination could be accelerated following broadcast seeding, the probability of successful establishment could be enhanced.

Alternate wetting and drying preplanting seed treatments have been shown to accelerate seedling emergence in several grasses (Keller and Bleak 1968; Bleak and Keller 1972, 1974). The beneficial effect of such treatments is more pronounced as the soil moisture content is reduced (Keller et al. 1970; Chippendale 1934). The response of seeds to an alternate wetting and drying treatment varies with the species (Griswold 1936; Bleak and Keller 1972; Chippendale 1934).

This paper reports the effects of an alternate wetting and drying seed treatment on the germination and root growth of Whitmar beardless wheatgrass under water potentials of $-0.3,-7.5$, and -15 bars.

\section{Materials and Methods}

Seed of Whitmar beardless wheatgrass used in this experiment was produced by the SCS Plant Materials Center at Pullman, Washington, in 1972 . Seed germination originally tested at $84 \%$ after 14 days at $20^{\circ} \mathrm{C}$.

\footnotetext{
Authors are former graduate research assistant, Department of Forestry and Range Management; range ecologist, Department of Forestry and Range Mangement; and agronomist, Department of Agronomy, Washington State University, Pullman 99164. Kastner's present address is 4925 th Avenue S.E., Salem, Oregon 97302.
}

The seeds were treated by placing them in petri dishes for 24 hours on two layers of blotter paper soaked with distilled water. They were kept at $20^{\circ} \mathrm{C}$ and received 8 hours of light during treatment. The seeds were then allowed to air-dry at room temperature in the laboratory for 24 hours. The temperature and relative humidity in the laboratory during the experiment were $21.2 \pm 2.2$ $\mathrm{C}^{\circ}$ and $33 \pm 8 \%$, respectively.

After drying, seeds were placed in slanted-plate containers, which allowed evaluation of germination, as well as measurement of root growth with a minimum amount of disturbance to the seeds. The slanted-plate containers consisted of covered plastic boxes which held 8 plastic plates. These plates were tilted at 9 degrees from vertical. Mannitol solution $1.2 \mathrm{~cm}$ deep, was placed in the bottom of each container. Solutions of D-mannitol were prepared using the formula provided by Helmerick and Pfeifer (1954) to simulate water potentials of $0.3,-7.5$, and -15 bars. This range of water potentials was chosen on the basis of previous work by McGinnies (1960).

Twenty-five equally spaced seeds were placed in a narrow groove across cach plate one-fourth of the way down from the top. A single layer of blotter paper, when moistened with the appropriate mannitol solutions, adhered to the back of each plate. The blotter paper provided moisture to the seeds and held them in place.

Each of three containers held seeds under a different water potential. In each container, four plates of treated seed and four plates of untreated seed were used. All containers were kept in a germinator at $20^{\circ} \mathrm{C}$ where they received 8 hours of light during each 24-hour period.

Germination percentage and root elongation were recorded at 24-hour intervals over a period of 9 days. A visible seminal root and coleoptile were used as the criteria for germination. Root measurements were taken on the first five developing seedlings on each plate.

Tests of significance for cumulative germination percentages and root length used the binomial confidence limits and the least significant difference, respectively.

\section{Results}

Cumulative germination percentages for treated and untreated seeds are shown in Figure 1. At a water potential of -0.3 bars, treated seeds began to germinate about 1 day ahead of the controls. On the fourth through the seventh day, the germination percentage for treated seeds was at least $17 \%$ higher than that of the untreated seeds. Germination at 9 days was also higher for treated seeds, but not significantly.

No significant differences between treated seeds and the controls were observed at a water potential of -7.5 bars. Treated seeds began to germinate 1 day earlier than the controls, but the controls showed a greater, although nonsignificant, germination percentage on the ninth day. 
conditions. Agron. J. 46:560-562.

Jones, R.L. 1969. Inhibition of gibberellic acid-induced $\alpha$-amylase formation by polyethylene glycol and mannitol. Plant Physiol. 44:101-104.

Keller, W., and A.T. Bleak. Preplanting treatment to hasten germination and emergence of grass seed. J. Range Manage. 21:213-216.

Keller, W.A., A.T. Bleak, and A.A. Hanson. 1970. Preplanting seed treatment may reduce failures in range seeding. p. 116-119. In: Proc. XI Internat. Grassland Congr. Univ. of Queesland Press, Queensland, Australia.

McGinnies, W.J. 1960. Effects of moisture stress and temperature on germination of six range grasses. Agron. J. 52:159-162.
Nelson, J.R., A.M. Wilson, and C.J. Goebel. 1970. Factors influencin broadcast seeding in bunchgrass range. J. Range Manage. 23:163-17(

Wilson, A.M. 1971. Amylase synthesis and stability in crested wheatgras seeds at low water potentials. Plant Physiol. 48:541-546.

Wilson, A.M. 1972. Measurement of seed response to environment. Range Manage. 25:482-483.

Wilson, A.M., and G.A. Harris. 1966. Hexose, inositol, and nucleosid phosphate esters in germinating seeds of crested wheatgrass. Plant Phy siol. 41:1416-1419.

Wilson, A.M., J.R. Nelson, and C.J. Goebel. 1970. Effects of environmer on the metabolism and germination of crested wheatgrass seeds. Rangc Manage. 23:283-288. 